\title{
MODEL PEMBELAJARAN REKONSTRUKSI SOSIAL BERBASIS MULTIKULTURALTERHADAP SIKAP SOSIAL DAN HASIL BELAJAR IPS
}

\author{
M.S. Hermaswari ${ }^{1}$, I.W. Lasmawan ${ }^{2}$, I.P. Sriartha ${ }^{3}$ \\ ${ }_{1,2,3}$ Program Studi Pendidikan IPS, Universitas Pendidikan Ganesha, Singaraja \\ e-mail: santhi.herma2@gmail.com ${ }^{1}$, wayan.lasmawan@pasca.undiksha.ac.id ${ }^{2}$, putusriartha@gmail.com ${ }^{3}$
}

\begin{abstract}
Abstrak
Penelitian ini bertujuan (1) untuk menganalisis perbedaan sikap sosial antara siswa yang mengikuti pembelajaran dengan model rekonstruksi sosial berbasis multikultur dengan siswa yang mengikuti pembelajaran dengan model konvensional, (2) Untuk menganalisis perbedaan hasil belajar IPS antara siswa yang mengikuti pembelajaran dengan model rekonstruksi sosial berbasis multikultur dengan siswa yang mengikuti pembelajaran dengan model konvensional, (3) untuk menganalisis perbedaan secara simultan sikap sosial dan hasil belajar IPS antara siswa yang mengikuti pembelajaran dengan model rekonstruksi sosial berbasis multikultur dengan siswa yang mengikuti pembelajaran dengan model konvensional di kelas IX SMP Negeri 4 Singaraja. Populasi dalam penelitian ini adalah siswa kelas IX SMP Negeri 4 Singaraja pada tahun ajaran 2019/2020 berjumlah 352 orang yang tersebar di sembilan kelas. Penentuan sampel penelitian dengan random sampling, ditentukan kelas IX B4 terpilih sebagai kelas eksperimen dan kelas IX B2 sebagai kelas kontrol dengan jumlah masing-masing sampel 32 orang. Data dikumpulkan dengan kuesioner dan tes. Data dianalisis dengan anava dan manova. Hasil penelitian menunjukkan bahwa: (1) terdapat perbedaan sikap sosial antara siswa yang mengikuti model pembelajaran rekonstruksi sosial berbasis multikultur dengan siswa yang mengikuti model pembelajaran konvensional dengan Fhitung $=51,053(p<0,05)$, (2) terdapat perbedaan hasil belajar IPS antara siswa yang mengikuti model pembelajaran rekonstruksi sosial berbasis multikultur dengan siswa yang mengikuti model pembelajaran konvensional dengan Fhitung $=189,749(p<0,05)$, dan (3) terdapat perbedaan sikap sosial dan hasil belajar IPS secara simultan antara siswa yang mengikuti model pembelajaran rekonstruksi sosial berbasis multikultur dengan siswa yang mengikuti model pembelajaran konvensional dengan FWilks' Lambda $=2821,588(p<0,05)$.
\end{abstract}

Kata kunci: Hasil Belajar IPS; Model Rekonstruksi Sosial Berbasis Multicultural; Sikap Sosial

\begin{abstract}
This study was aims (1) to analyze differences of social attitudes between students who followed the learning with social reconstruction models multicultural based and students who followed the learning with conventional models, (2) to analyze differences of IPS learning result between students who followed the learning with social reconstruction models multicultural based and students who followed the learning with conventional models, (3) to analyze the differences simultaneously of social attitudes and IPS learning result between students who followed the learning with social reconstruction models multicultural based and students who followed the learning with conventional models at ninth grade of SMP Negeri 4 Singaraja. The population in this study were students of ninth grade of SMP Negeri 4 Singaraja in academic year 2019/2020 amounted to 352 student spread in nine classes. Determination of research sample with ramdom sampling, the grade IX B4 was selected as the experimental class and the grade IX B2 as the control class with the sum of 32 samples each. Data were collected with questionnaires and tests. The data were analyzed by one-way ANOVA and manova. The results showed that: (1) there was differences of social attitudes between students who followed the learning with social reconstruction models multicultural based and students who followed the learning with conventional models with Fcount $=51.053(p<0.05)$, (2) there was differences of IPS learning result between students who followed the learning with social reconstruction models multicultural based and students who followed the learning with conventional models with Fcount = $189.749(p<0.05)$, and (3) there were difference of social attitudes and IPS learning result simultaneously between students who followed the learning with social reconstruction models multicultural based and students who followed the learning with conventional models with FWilks'Lambda $=2821.588(p<0.05)$.
\end{abstract}

Keywords: IPS Learning Result; Social Reconstruction Models Multicultural Based; Social Attitudes 


\section{PENDAHULUAN}

Selama ini pembelajaran IPS sering menuai kritik dari berbagai kalangan yang cenderung mendeskripsikan pelajaran IPS dimata peserta didik adalah mata pelajaran yang membosankan dan terlalu sarat dengan materi penghafalan, sehingga tidak menggugah peserta didik untuk mempelajarinya. Sesungguhnya pembelajaran pendidikan IPS merupakan suatu program pendidikan yang mengintegrasikan konsep-konsep ilmu sosial dan humaniora dengan tujuan utama untuk membentuk warga negara yang baik dan berkompeten (Lasmawan, 2019). Pendidikan IPS berfungsi sebagai ilmu pengetahuan dalam mengembangkan kemampuan dan sikap rasional dalam menanggapi kenyataan sosial atau permasalahan sosial beserta perkembangan masyarakat dunia. Melalui pembelajaran IPS, berusaha membantu siswa dari sejak dini untuk selalu berupaya memecahkan pemasalahan yang dihadapi sehingga akan menjadikannya semakin mengerti dan memahami lingkungan sosial masyarakatnya (Cleaf dalam Lasmawan, 2010). Dengan demikian diperlukan sebuah model pembelajaran yang dapat membantu siswa untuk mampu mengatasi atau memecahkan masalah secara konstruktif. Eksistensi dan nilai strategis sebuah model pembelajaran semakin penting manakala guru sebagai ujung tombak pembelajaran belum memiliki wawasan dan keterampilan instruksional yang memadai, sehingga dalam aktivitas akademiknya guru masih membutuhkan acuan sebuah model pembelajaran untuk menterjadikan pembelajaran itu bermakna bagi siswanya (Benyamin, 2010).

Pembelajaran IPS sebagai salah satu program pendidikan nasional yang diberlakukan secara nasional pada tataran sekolah menengah pertama (SMP), memiliki peran yang sangat strategis dalam kaitannya dengan pengembangan dan penyiapan SDM yang berkualitas bagi bangsa Indonesia. Namun fakta yang ada di lapangan menunjukkan bahwa pembelajaran IPS masih dihadapkan pada berbagai persoalan yang menyangkut esensi dan nilai kemanfaatannya bagi siswa dan masyarakat. Pendidikan IPS masih dipandang sebagai mata pelajaran kelas dua dan tidak bermanfaat bagi siswa dalam menjalani kehidupannya di masyarakat (Lasmawan, 2010). Disisi lain, cara guru membelajarkan pendidikan IPS juga masih terbatas pada persoalan penanaman konsep, faktadan rangkaian peristiwa, sehingga cenderung membosankan bagi siswa.

Telah banyak penelitian dilakukan terkait dengan dimensi pembelajaran IPS, termasuk untuk jenjang SMP. Kaji petik Dantes (2014) menyimpulkan bahwa penelitian-penelitian pendidikan yang dilakukan oleh kalangan praktisi pendidikan di LPTK lebih banyak menyentuh aras instruksional dan penilaian, dan sangat sedikit yang berani menyentuh aras konstruksi keilmuan atau batang tubuh disiplin ilmu. Sementara NCSS (2017) menyatakan bahwa konstruksi pendidikan IPS dan kurikulum standar pada semua jenjangnya masih memerlukan kajian-kajian akademis dari kalangan praktisi dan teoritisi untuk memperkuat dan memperdalam kebermaknaan dari pendidikan IPS itu sendiri. Sejalan dengan perubahan paradigma pembelajaran IPS dari paradigma "mainstream academic knowledge" ke paradigma "transformative academic knowledge", maka rekonstruksi dasar-dasar pemikiran kurikulum IPS sejalan dengan perkembangan paradigma pendidikan mutakhir, yakni menuju aplikasi teori rekonstruksi sosial Vygotsky yang lebih bijaksana dan akomodatif bagi perkembangan kemanusiaan secara instruksional.

Fakta menunjukkan bahwa komitmen untuk menjadikan teori rekonstruksi sosial sebagai paradigma baru IPS di Indonesia, belum banyak didukung oleh hasil-hasil penelitian kontekstual. Beberapa penelitian yang telah dilakukan belum menjangkau dimensi-dimensi rekayasa sosial terstruktur sebagai inti dari teori rekonstruksi sosial dalam pengembangan dan penerapan kurikulum IPS. Salah satu model pembelajaran yang disinyalir mampu mengatasi kesenjangan tersebut adalah model rekonstruksi sosial Vygotsky. Model pembelajaran ini lebih menyandarkan pada keberpihakan pada siswa untuk membangun pengetahuannya sendiri dengan fasilitasi guru, sehingga hasil belajar mereka lebih optimal (Haris, 2018). Model belajar rekonstruksi sosial Vygotsky merupakan sebuah rangkaian instruksional yang tertata sedemikian rupa dengan menempatkan siswa sebagai sentra pembelajaran, dimana guru lebih bertindak sebagai fasilitator dan mediator pembelajaran. Model ini lebih berorientasi pada pengembangan dan optimalisasi potensi dan keterampilan berpikir kritis siswa melalui keterampilan instruksional yang terstruktur (Lasmawan, 2019). 
Model pembelajaran rekonstruksi sosial pada hakikatnya mengembalikan atau membangun kembali esensi dari pendidikan IPS dengan memanfaatkan kelas dan sekolah sebagai laboratorium masyarakat siswa (Adnyana dkk., 2013). Interaksi sosial menjadi kunci dari model pembelajaran Rekonstruksi Sosial ini, karena model ini merujuk pada bagaimana siswa merekonstruksi pengetahuannya sendiri melalui interaksi pada lingkungan sosial dan budayanya. Dengan model pembelajaran rekonstruksi sosial ini, siswa diharapkan mampu menumbuhkembangkan sikap sosial pada dirinya dan mampu mengoptimalkan daya pikir mereka dalam memecahkan masalah-masalah nyata yang mereka hadapi di masyarakat.

Model rekonstruksi sosial sangat akomodatif terhadap nilai-nilai budaya dan phenomena sosial lain yang ada di masyarakat. Keberagaman masyarakat, secara asimilatif terelaborasi dalam pembelajaran dengan menggunakan model ini. Terkait dengan hal itu, maka model pembelajaran rekonstruksi sosial yang akan diujikan dalam penelitian ini adalah model yang disandarkan dan berintikan pada nilai-nilai keberagaman (multikultur) dalam aktivitas instruksional. Artinya bahwa bagaimana model itu disandarkan pada nilai-nilai multikultur yang ada di tengah-tengah masyarakat. Hal ini sejalan dengan apa yang dikedepankan oleh Banks (2009), bahwa nilai-nilai multikultur sangat mendesak sifatnya untuk diintegrasikan dalam kegiatan-kegiatan instruksional, agar para siswa dengan dini memahami bagaimana mereka berpikir, bersikap, dan berperilaku di tengah-tengah masyarakat yang multi etnis. Penelitian Haris (2018) menyimpulkan bahwa pendidikan multikultur dalam konstruksi budaya dalam pembelajaran IPS secara signifikan dapat meningkatkan aktivitas dan hasil belajar siswa dengan kontribusi $82.03 \%$. Sementara Farisi dan Imam (2015) dalam penelitiannya menyimpulkan bahwa penerapan model pembelajaran rekonstruksi sosial Vygotsky berbasis multikultur secara signifikan berpengaruh pada perolehan belajar dan meningkatnya sikap dan perilaku multikultur siswa.

Berdasarkan latar belakang dan beberapa kajian akademis di atas, maka penelitian ini akan diarahkan pada upaya pengujian terhadap model rekonstruksi sosial Vygotsky berbasis multikultur dalam kaitannya dengan sikap sosial dan hasil belajar siswa dalam pembelajaran IPS. Melalui serangkaian tindakan yang terencana dan bertujuan, penelitian ini lebih diarahkan pada upaya untuk mengetahui bagaimana pengaruh model rekonstruksi sosial berbasis multikultur terhadap sikap sosial dan hasil belajar siswa, dengan menjadikan siswa di SMP Negeri 4 Singaraja sebagai lokasi penelitian.

\section{METODE}

Penelitian ini dikatagorikan kuasi eksperimen. Desain ini dipilih karena eksperimen dilakukan di beberapa kelas tertentu dengan siswa yang telah ada atau sebagaimana adanya. Rancangan eksperimen yang dipilih adalah rancangan Non-Equivalent Post-Test Only Control Group Design. Populasi dalam penelitian ini adalah seluruh siswa kelas IX SMP Negeri 4 Singaraja pada tahun ajaran 2019/2020, dengan jumlah 352 orang yang tersebar dalam sembilan kelas pararel. Berdasarkan hasil kesetaraan semua kelas IX SMP Negeri 4 Singaraja memiliki kemampuan yang setara maka bisa dilakukan dengan random sampling. Dua kelas dijadikan sampel penelitian, satu kelas sebagai kelas eksperimen dan satu kelas sebagai kelas kontrol. Data dikumpulkan dengan kuesioner dan tes serta dianalisis dengan anova dan manova dengan uji $\mathrm{F}$.

\section{HASIL DAN PEMBAHASAN Hasil}

Hipotesis pertama yang diajukan dalam penelitian ini adalah terdapat perbedaan sikap sosial terhadap siswa yang mengikuti model pembelajaran rekonstruksi sosial berbasis multikultur dan siswa yang mengikuti model pembelajaran konvensional di kelas IX SMP N 4 Singaraja. Pengujian hipotesis pertama dengan analisis varian satu jalur. Hipotesis yang diuji secara statistik adalah $\mathrm{H}_{0}$. Kriteria penolakan $\mathrm{H}_{0}$ jika harga $\mathrm{F}$ memiliki angka signifikansi lebih kecil dari 0,05. Rekapitulasi hasil analisis varian satu jalur disajikan pada Tabel 1. 
Tabel 1. Rekapitulasi Hasil Analisis Varian Satu Jalur untuk Sikap Sosial ANOVA

\begin{tabular}{lccccc}
\hline & Sum of Squares & $d f$ & Mean Square & $F$ & Sig. \\
\hline Between Groups & 4290,250 & 1 & 4290,250 & 51,053 & 0,000 \\
Within Groups & 5210,188 & 62 & 84,035 & & \\
Total & 9500,438 & 63 & & & \\
\hline
\end{tabular}

Berdasarkan rekapitulasi hasil analisis varian satu jalur yang disajikan pada Tabel 1 dapat ditunjukkan bahwa nilai $F=51,053(p<0,05)$, sehingga $H_{0}$ yang menyatakan tidak terdapat perbedaan sikap sosial terhadap siswa yang mengikuti model pembelajaran rekonstruksi sosial berbasis multikultur dan siswa yang mengikuti model pembelajaran konvensional di kelas IX SMP N 4 Singaraja ditolak. Jadi, terdapat perbedaan sikap sosial terhadap siswa yang mengikuti model pembelajaran rekonstruksi sosial berbasis multikultur dan siswa yang mengikuti model pembelajaran konvensional di kelas IX SMP N 4 Singaraja.

Hipotesis kedua yang diajukan dalam penelitian ini adalah terdapat perbedaan hasil belajar IPS terhadap siswa yang mengikuti model pembelajaran rekonstruksi sosial berbasis multikultur dan siswa yang mengikuti model pembelajaran konvensional di kelas IX SMP N 4 Singaraja. Pengujian hipotesis kedua dengan analisis varian satu jalur. Hipotesis yang diuji secara statistik adalah $\mathrm{H}_{0}$. Kriteria penolakan $\mathrm{H}_{0}$ jika harga $\mathrm{F}$ memiliki angka signifikansi lebih kecil dari 0,05. Rekapitulasi hasil analisis varian satu jalur disajikan pada Tabel 2.

Tabel 2. Rekapitulasi Hasil Analisis Varian Satu Jalur untuk Hasil Belajar IPS

ANOVA

\begin{tabular}{lccccc}
\hline & Sum of Squares & $d f$ & Mean Square & $F$ & Sig. \\
\hline Between Groups & 6162,250 & 1 & 6162,250 & 189,749 & 0,000 \\
Within Groups & 2013,500 & 62 & 32,476 & & \\
Total & 8175,750 & 63 & & & \\
\hline
\end{tabular}

Berdasarkan rekapitulasi hasil analisis varian satu jalur yang disajikan pada Tabel 2 dapat ditunjukkan bahwa nilai $F=189,749(\mathrm{p}<0,05)$, sehingga $\mathrm{H}_{0}$ yang menyatakan tidak terdapat perbedaan hasil belajar IPS terhadap siswa yang mengikuti model pembelajaran rekonstruksi sosial berbasis multikultur dan siswa yang mengikuti model pembelajaran konvensional di kelas IX SMP N 4 Singaraja ditolak. Jadi, terdapat perbedaan hasil belajar IPS terhadap siswa yang mengikuti model pembelajaran rekonstruksi sosial berbasis multikultur dan siswa yang mengikuti model pembelajaran konvensional di kelas IX SMP N 4 Singaraja.

Hipotesis ketiga yang diajukan dalam penelitian ini adalah terdapat perbedaan sikap sosial dan hasil belajar IPS secara simultan terhadap siswa yang mengikuti model pembelajaran rekonstruksi sosial berbasis multikultur dan siswa yang mengikuti model pembelajaran konvensional di kelas IX SMP N 4 Singaraja. Pengujian hipotesis ketiga dengan manova. Hipotesis yang diuji secara statistik adalah $\mathrm{H}_{0}$. Kriteria penolakan $\mathrm{H}_{0}$ jika taraf signifikansi untuk statistik Wilks' Lambda lebih kecil dari 0,05. Rekapitulasi hasil hasil uji manova tersaji pada Tabel 3.

Tabel 3. Rekapitulasi Hasil Manova Multivariate Tests

\begin{tabular}{lccccc}
\hline \multicolumn{1}{c}{ Effect } & Value & $F$ & Hypothesis df & Error df & Sig. \\
\hline Pillai's Trace & 0,989 & 2821,588 & 2,000 & 61,000 & 0,000 \\
Wilks' Lambda & 0,011 & 2821,588 & 2,000 & 61,000 & 0,000 \\
Hotelling's Trace & 92,511 & 2821,588 & 2,000 & 61,000 & 0,000 \\
Roy's Largest Root & 92,511 & 2821,588 & 2,000 & 61,000 & 0,000 \\
\hline
\end{tabular}

Berdasarkan ringkasan analisis manova yang disajikan pada Tabel 3 , dapat diinterpretasikan bahwa taraf signifikansi untuk nilai F-Wilks' Lambda $=2821,588(p<0,05)$, sehingga $\mathrm{H}_{0}$ yang menyatakan tidak terdapat perbedaan sikap sosial dan hasil belajar IPS secara simultan terhadap siswa yang mengikuti model pembelajaran rekonstruksi sosial 
berbasis multikultur dan siswa yang mengikuti model pembelajaran konvensional di kelas IX SMP N 4 Singaraja ditolak. Jadi, terdapat perbedaan sikap sosial dan hasil belajar IPS secara simultan terhadap siswa yang mengikuti model pembelajaran rekonstruksi sosial berbasis multikultur dan siswa yang mengikuti model pembelajaran konvensional di kelas IX SMP N 4 Singaraja.

\section{Pembahasan}

Untuk permasalahan pertama, hasil analisis dengan analisis varians satu jalur diperoleh bahwa nilai $F=51,053(p<0,05)$. Oleh karena itu, hipotesis nol $\left(H_{0}\right)$ yang menyatakan bahwa tidak terdapat perbedaan sikap sosial terhadap siswa yang mengikuti model pembelajaran rekonstruksi sosial berbasis multikultur dan siswa yang mengikuti model pembelajaran konvensional di kelas IX SMP N 4 Singaraja ditolak. Jadi, terdapat perbedaan sikap sosial terhadap siswa yang mengikuti model pembelajaran rekonstruksi sosial berbasis multikultur dan siswa yang mengikuti model pembelajaran konvensional di kelas IX SMP N 4 Singaraja.

Hasil analisis deskriptif menunjukkan bahwa perbedaan sikap sosial siswa yang mengikuti model pembelajaran rekonstruksi sosial berbasis multikultur dengan skor rata-rata 121,53, sedangkan sikap sosial siswa yang mengikuti model pembelajaran konvensional dengan skor rata-rata 105,16 . Ternyata skor rata-rata sikap sosial siswa yang mengikuti model pembelajaran rekonstruksi sosial berbasis multikultur lebih tinggi daripada siswa yang mengikuti model pembelajaran konvensional. Dengan demikian, dapat disimpulkan sikap sosial siswa yang mengikuti model pembelajaran rekonstruksi sosial berbasis multikultur lebih unggul daripada siswa yang mengikuti model pembelajaran konvensional.

Sikap seseorang selalu berhubungan dengan kehidupan sosial, karena dengan adanya interaksi sosial akan terlihat sikap seseorang tersebut (Tiara dan Sari, 2019). Sikap sosial berkembang dalam suatu interaksi dalam kelompok sosial yang dinyatakan dengan cara yang sama dan dilakukan berulang-ulang. Oleh karena itu, model pembelajaran rekonstruksi sosial berbasis multikultur sangat sesuai diterapkan untuk mengembangkan sikap sosial siswa. Hal ini disebabkan karena interaksi sosial menjadi kunci dari model pembelajaran rekonstruksi sosial ini, karena model ini merujuk pada bagaimana siswa merekonstruksi pengetahuannya sendiri melalui interaksi pada lingkungan sosial dan budayanya (Adnyana dkk., 2013). Rekonstruksi sosial berfokus pada mendidik siswa tentang permasalahan yang terjadi di masyarakat mereka. Tujuannya adalah untuk memberikan pemahaman kepada siswa, memberi mereka keterampilan yang mereka butuhkan untuk dapat mengambil tindakan dengan apa yang mereka pelajari, mendorong mereka untuk meningkatkan kemampuan bermasyarakat (Nalova, 2017).

Model rekonstruksi sosial sangat akomodatif terhadap nilai-nilai budaya dan phenomena sosial lain yang ada di masyarakat. Keberagaman masyarakat, secara asimilatif terelaborasi dalam pembelajaran dengan menggunakan model ini. Terkait dengan hal itu, maka model pembelajaran rekonstruksi sosial yang akan diujikan dalam penelitian ini adalah model yang disandarkan dan berintikan pada nilai-nilai keberagaman (multikultur) dalam aktivitas instruksional. Artinya bahwa bagaimana model itu disandarkan pada nilai-nilai multikultur yang ada di tengah-tengah masyarakat. Hal ini sejalan dengan apa yang dikedepankan oleh Banks (2009), bahwa nilai-nilai multikultur sangat mendesak sifatnya untuk diintegrasikan dalam kegiatan-kegiatan instruksional, agar para siswa dengan dini memahami bagaimana mereka bersikap dan berperilaku. Dengan model pembelajaran rekonstruksi sosial berbasis multikultur, siswa diharapkan mampu menumbuhkan dan mengembangkan sikap sosial pada dirinya dalam memecahkan masalah-masalah nyata yang mereka hadapi di masyarakat.

Berbeda dengan dalam pembelajaran IPS dengan menggunakan pembelajaran konvensional, lebih menekankan pada fungsi guru sebagai pemberi informasi. Siswa hanya pasif mendengarkan penjelasan guru tanpa dilibatkan secara aktif dalam pembelajaran. Guru menjelaskan dari konsep, definisi, pengertian sampai pada contoh-contoh. Siswa baru terlibat jika ada soal yang diberikan oleh guru dan lebih bersifat hafalan. Kreatifitas siswa 
kurang berkembang, sehingga akan berakibat pada kurang maksimalnya sikap sosial siswa karena sangat jarang memberikan kepada siswa untuk berpendapat.

Secara empiris, hasil penelitian ini didukung oleh hasil penelitian terdahulu yang dilakukan oleh Farisi dan Imam (2015) dalam penelitiannya menyimpulkan bahwa penerapan model pembelajaran rekonstruksi sosial Vygotsky berbasis multikultur secara signifikan berpengaruh pada perolehan belajar dan meningkatnya sikap dan perilaku multikultur siswa. Senada dengan itu, hasil penelitian yang dilakukan oleh Pranata (2013) juga menunjukkan bahwa sikap sosial siswa yang mengikuti pembelajaran dengan model rekonstruksi sosial Vygotsky teknik scaffolding secara signifikan lebih baik daripada siswa yang mengikuti pembelajaran dengan model konvensional.

Hasil penelitian seperti yang disebutkan di atas tampak bahwa model pembelajaran rekonstruksi sosial berbasis multikultur berpengaruh terhadap sikap sosial siswa. Dengan demikian dapat disimpulkan bahwa terdapat perbedaan sikap sosial terhadap siswa yang mengikuti model pembelajaran rekonstruksi sosial berbasis multikultur dan siswa yang mengikuti model pembelajaran konvensional di kelas IX SMP N 4 Singaraja terbukti secara teoretis dan empiris.

Untuk permasalahan kedua, hasil analisis dengan analisis varians satu jalur diperoleh bahwa nilai $F=189,749(p<0,05)$. Oleh karena itu, hipotesis nol $\left(\mathrm{H}_{0}\right)$ yang menyatakan bahwa tidak terdapat perbedaan hasil belajar IPS terhadap siswa yang mengikuti model pembelajaran rekonstruksi sosial berbasis multikultur dan siswa yang mengikuti model pembelajaran konvensional di kelas IX SMP N 4 Singaraja ditolak. Jadi, terdapat perbedaan hasil belajar IPS terhadap siswa yang mengikuti model pembelajaran rekonstruksi sosial berbasis multikultur dan siswa yang mengikuti model pembelajaran konvensional di kelas IX SMP N 4 Singaraja.

Hasil analisis deskriptif menunjukkan bahwa perbedaan hasil belajar IPS siswa yang mengikuti model pembelajaran rekonstruksi sosial berbasis multikultur dengan skor rata-rata 77,88 , sedangkan hasil belajar IPS siswa yang mengikuti model pembelajaran konvensional dengan skor rata-rata 58,25. Ternyata skor rata-rata hasil belajar IPS siswa yang mengikuti model pembelajaran rekonstruksi sosial berbasis multikultur lebih tinggi daripada siswa yang mengikuti model pembelajaran konvensional. Dengan demikian, dapat disimpulkan hasil belajar IPS siswa yang mengikuti model pembelajaran rekonstruksi sosial berbasis multikultur lebih unggul daripada siswa yang mengikuti model pembelajaran konvensional.

Proses pembelajaran dapat berjalan dengan baik dibutuhkan peran aktif dengan didukung perencanaan yang sistematis oleh guru. Guru harus mampu mengembangkan diri dalam melaksanakan kegiatan pembelajaran yang bertujuan mengoptimalkan hasil belajar IPS siswa. Guru memegang peranan penting dalam proses pembelajaran, kemampuan guru menciptakan suasana dan lingkungan yang menarik serta menyenangkan siswa akan kualitas hasil belajar agar siswa tidak merasa bosan dengan proses yang ada dengan menerapkan model pembelajaran yang tepat. Pada dasarnya model rekonstruksi sosial merupakan sebuah pembelajaran yang berpusat pada siswa dan memiliki tujuan untuk memahami dan menghadapi isu-isu atau masalah-masalah sosial yang terjadi di masyarakat, serta menjadikan siswa sebagai aktor dalam perubahan dan perbaikan kondisi sosial menuju yang lebih baik (Pranata, 2013). Oleh karena itu, model pembelajaran rekonstruksi sosial berbasis multikultur sangat sesuai untuk mengembangkan hasil belajar siswa karena pembelajaran berpusat pada siswa dan memiliki tujuan untuk memahami dan menghadapi isu-isu atau masalah-masalah sosial serta menciptakan suasana dan lingkungan yang menarik serta menyenangkan siswa akan kualitas hasil belajar.

Model pembelajaran ini lebih menyandarkan pada keberpihakan pada siswa untuk membangun pengetahuannya sendiri dengan fasilitasi guru, sehingga hasil belajar mereka lebih optimal (Haris, 2018). Model belajar rekonstruksi sosial Vygotsky merupakan sebuah rangkaian instruksional yang tertata sedemikian rupa dengan menempatkan siswa sebagai sentra pembelajaran, dimana guru lebih bertindak sebagai fasilitator dan mediator pembelajaran. Model ini lebih berorientasi pada pengembangan dan optimalisasi potensi dan keterampilan berpikir siswa melalui keterampilan instruksional yang terstruktur (Lasmawan, 2019). Rekonstruksi sosial berfokus pada mendidik siswa tentang permasalahan yang terjadi 
di masyarakat mereka. Tujuannya adalah untuk memberikan pemahaman kepada siswa dan memberi mereka keterampilan yang mereka butuhkan untuk dapat mengambil tindakan dengan apa yang mereka pelajari, (Nalova, 2017).

Model rekonstruksi sosial sangat akomodatif terhadap nilai-nilai budaya dan phenomena sosial lain yang ada di masyarakat. Keberagaman masyarakat, secara asimilatif terelaborasi dalam pembelajaran dengan menggunakan model ini. Terkait dengan hal itu, maka model pembelajaran rekonstruksi sosial yang akan diujikan dalam penelitian ini adalah model yang disandarkan dan berintikan pada nilai-nilai keberagaman (multikultur) dalam aktivitas instruksional. Artinya bahwa bagaimana model itu disandarkan pada nilai-nilai multikultur yang ada di tengah-tengah masyarakat. Hal ini sejalan dengan apa yang dikedepankan oleh Banks (1993), bahwa nilai-nilai multikultur sangat mendesak sifatnya untuk diintegrasikan dalam kegiatan-kegiatan instruksional, agar para siswa dengan dini memahami bagaimana mereka berpikir. Dengan model pembelajaran rekonstruksi sosial berbasis multikultur, siswa diharapkan mampu meningkatkan kualitas hasil belajarnya dalam memecahkan masalah-masalah nyata yang mereka hadapi di masyarakat.

Berbeda dengan pembelajaran IPS dengan menggunakan pembelajaran konvensional, siswa kurang mendapatkan kesempatan belajar dengan pengalaman sehari-hari. Dengan demikian, belajar IPS seolah-seolah belajar konsep-konsep atau prinsip-prinsip IPS yang tidak ada kaitannya dengan kehidupan anak. Oleh karena itu, pengetahuan anak tentang IPS sebatas pengetahuan yang ada pada buku serta apa yang diberikan oleh guru. Hal ini akan melemahkan semangat siswa untuk belajar, sehingga hasil belajar siswa tidak tercapai secara optimal.

Secara empiris, hasil penelitian ini didukung oleh hasil penelitian terdahulu yang dilakukan oleh Pranata (2013) menunjukkan bahwa prestasi belajar IPS siswa yang mengikuti pembelajaran dengan model rekonstruksi sosial Vygotsky teknik scaffolding secara signifikan lebih baik daripada siswa yang mengikuti pembelajaran dengan model konvensional. Senada dengan itu, hasil penelitian yang dilakukan oleh Haris (2018) menyimpulkan bahwa pendidikan multikultur dalam konstruksi budaya dalam pembelajaran IPS secara signifikan dapat meningkatkan hasil belajar siswa.

Hasil penelitian seperti yang disebutkan di atas tampak bahwa model pembelajaran rekonstruksi sosial berbasis multikultur berpengaruh terhadap hasil belajar IPS siswa. Dengan demikian dapat disimpulkan bahwa terdapat perbedaan hasil belajar IPS terhadap siswa yang mengikuti model pembelajaran rekonstruksi sosial berbasis multikultur dan siswa yang mengikuti model pembelajaran konvensional di kelas IX SMP N 4 Singaraja terbukti secara teoretis dan empiris.

Untuk permasalahan ketiga, hasil analisis dengan manova tampak bahwa nilai F-Wilks' Lambda $=2821,588(\mathrm{p}<0,05)$. Oleh karena itu, hipotesis nol $\left(\mathrm{H}_{0}\right)$ yang menyatakan bahwa tidak terdapat perbedaan sikap sosial dan hasil belajar IPS secara simultan terhadap siswa yang mengikuti model pembelajaran rekonstruksi sosial berbasis multikultur dan siswa yang mengikuti model pembelajaran konvensional di kelas IX SMP N 4 Singaraja ditolak. Jadi, terdapat perbedaan sikap sosial dan hasil belajar IPS secara simultan terhadap siswa yang mengikuti model pembelajaran rekonstruksi sosial berbasis multikultur dan siswa yang mengikuti model pembelajaran konvensional di kelas IX SMP N 4 Singaraja.

Sikap seseorang selalu berhubungan dengan kehidupan sosial, karena dengan adanya interaksi sosial akan terlihat sikap seseorang tersebut (Tiara dan Sari, 2019). Sikap sosial berkembang dalam suatu interaksi dalam kelompok sosial yang dinyatakan dengan cara yang sama dan dilakukan berulang-ulang. Oleh karena itu, model pembelajaran rekonstruksi sosial berbasis multikultur sangat sesuai diterapkan untuk mengembangkan sikap sosial siswa. Hal ini disebabkan karena interaksi sosial menjadi kunci dari model pembelajaran rekonstruksi sosial ini, karena model ini merujuk pada bagaimana siswa merekonstruksi pengetahuannya sendiri melalui interaksi pada lingkungan sosial dan budayanya (Adnyana dkk., 2013). Rekonstruksi sosial berfokus pada mendidik siswa tentang permasalahan yang terjadi di masyarakat mereka. Tujuannya adalah untuk memberikan pemahaman kepada siswa, memberi mereka keterampilan yang mereka butuhkan untuk dapat mengambil 
tindakan dengan apa yang mereka pelajari, mendorong mereka untuk meningkatkan kemampuan bermasyarakat (Nalova, 2017).

Proses pembelajaran dapat berjalan dengan baik dibutuhkan peran aktif dengan didukung perencanaan yang sistematis oleh guru. Guru harus mampu mengembangkan diri dalam melaksanakan kegiatan pembelajaran yang bertujuan mengoptimalkan hasil belajar IPS siswa. Guru memegang peranan penting dalam proses pembelajaran, kemampuan guru menciptakan suasana dan lingkungan yang menarik serta menyenangkan siswa akan kualitas hasil belajar agar siswa tidak merasa bosan dengan proses yang ada dengan menerapkan model pembelajaran yang tepat. Pada dasarnya model rekonstruksi sosial merupakan sebuah pembelajaran yang berpusat pada siswa dan memiliki tujuan untuk memahami dan menghadapi isu-isu atau masalah-masalah sosial yang terjadi di masyarakat, serta menjadikan siswa sebagai aktor dalam perubahan dan perbaikan kondisi sosial menuju yang lebih baik (Pranata, 2013). Oleh karena itu, model pembelajaran rekonstruksi sosial berbasis multikultur sangat sesuai untuk mengembangkan hasil belajar siswa karena pembelajaran berpusat pada siswa dan memiliki tujuan untuk memahami dan menghadapi masalah-masalah sosial serta menciptakan suasana yang menarik serta menyenangkan siswa akan kualitas hasil belajar.

Model rekonstruksi sosial sangat akomodatif terhadap nilai-nilai budaya dan phenomena sosial lain yang ada di masyarakat. Keberagaman masyarakat, secara asimilatif terelaborasi dalam pembelajaran dengan menggunakan model ini. Terkait dengan hal itu, maka model pembelajaran rekonstruksi sosial yang akan diujikan dalam penelitian ini adalah model yang disandarkan dan berintikan pada nilai-nilai keberagaman (multikultur) dalam aktivitas instruksional. Artinya bahwa bagaimana model itu disandarkan pada nilai-nilai multikultur yang ada di tengah-tengah masyarakat. Hal ini sejalan dengan apa yang dikedepankan oleh Banks (2007), bahwa nilai-nilai multikultur sangat mendesak sifatnya untuk diintegrasikan dalam kegiatan-kegiatan instruksional, agar para siswa dengan dini memahami bagaimana mereka berpikir dan bersikap. Dengan model pembelajaran rekonstruksi sosial berbasis multikultur, siswa diharapkan mampu meningkatkan sikap sosial dan kualitas hasil belajarnya dalam memecahkan masalah-masalah nyata yang mereka hadapi di masyarakat.

Berbeda dengan pembelajaran IPS dengan menggunakan pembelajaran konvensional, lebih menekankan pada fungsi guru sebagai pemberi informasi. Siswa hanya pasif mendengarkan penjelasan guru tanpa dilibatkan secara aktif dalam pembelajaran. Guru menjelaskan dari konsep, definisi, pengertian sampai pada contoh-contoh. Siswa baru terlibat jika ada soal yang diberikan oleh guru dan lebih bersifat hafalan. Kreatifitas siswa kurang berkembang, sehingga akan berakibat pada kurang maksimalnya hasil belajar siswa. Sebagai bentuk perbandingan, pembelajaran konvensional lebih didominasi oleh kegiatan guru untuk memberikan instruksi atau ceramah selama proses pembelajaran berlangsung. Hal ini jelas akan menempatkan siswa sebagai penerima informasi yang pasif dan hanya menerima informasi dari guru. Proses pembelajaran cenderung kurang didasarkan pada pengalaman siswa. Hal ini kurang memberikan kesempatan mengembangkan sikap sosial dan hasil belajar IPS siswa.

Secara empiris, hasil penelitian ini didukung oleh hasil penelitian terdahulu yang dilakukan oleh Pranata (2013) yang berjudul "Pengaruh Implementasi Model Rekonstruksi Sosial Vigotsky Dengan Teknik Scaffolding Terhadap Sikap Sosial Dan Prestasi Belajar IPS" Hasil penelitian menunjukkan bahwa sikap sosial siswa yang mengikuti pembelajaran dengan model rekonstruksi sosial Vygotsky teknik scaffolding secara signifikan lebih baik daripada siswa yang mengikuti pembelajaran dengan model konvensional $(F=23,108$; $p<$ $0,05)$. Hasil penelitian juga menunjukkan prestasi belajar IPS siswa yang mengikuti pembelajaran dengan model rekonstruksi sosial Vygotsky teknik scaffolding secara signifikan lebih baik daripada siswa yang mengikuti pembelajaran dengan model konvensional $(\mathrm{F}=$ $37,555 ; p<0,05)$.

Hasil penelitian seperti yang disebutkan di atas tampak bahwa model pembelajaran rekonstruksi sosial berbasis multikultur berpengaruh terhadap sikap sosial dan hasil belajar IPS siswa. Dengan demikian dapat disimpulkan bahwa terdapat perbedaan sikap sosial dan 
hasil belajar IPS secara simultan terhadap siswa yang mengikuti model pembelajaran rekonstruksi sosial berbasis multikultur dan siswa yang mengikuti model pembelajaran konvensional di kelas IX SMP N 4 Singaraja terbukti secara teoretis dan empiris.

\section{SIMPULAN DAN SARAN}

Berdasarkan analisis data dan pembahasan seperti yang telah diuraikan pada bagian sebelumnya, dapat ditemukan beberapa hal, yaitu (1) terdapat perbedaan sikap sosial antara siswa yang mengikuti model pembelajaran rekonstruksi sosial berbasis multikultur dengan siswa yang mengikuti model pembelajaran konvensional dengan Fhitung $=51,053(\mathrm{p}<$ $0,05)$; (2) terdapat perbedaan hasil belajar IPS antara siswa yang mengikuti model pembelajaran rekonstruksi sosial berbasis multikultur dengan siswa yang mengikuti model pembelajaran konvensional dengan Fhitung $=189,749(p<0,05)$; dan (3) terdapat perbedaan sikap sosial dan hasil belajar IPS secara simultan antara siswa yang mengikuti model pembelajaran rekonstruksi sosial berbasis multikultur dengan siswa yang mengikuti model pembelajaran konvensional dengan FWilks' Lambda $=2821,588(p<0,05)$.

Berkenaan dengan hasil penelitian yang diperoleh, guru disarankan menggunakan model pembelajaran rekonstruksi sosial berbasis multikultur sebagai upaya untuk meningkatkan sikap sosial dan hasil belajar IPS siswa. Dalam kegiatan belajar mengajar di kelas, guru disarankan agar tidak hanya terfokus pada satu metode mengajar saja agar peserta didik tidak cepat merasa bosan dalam kegiatan pembelajaran. Dari pemahaman tersebut, guru diharapkan dapat: (1) guru mempersiapkan media untuk mendukung metode pembelajaran, (2) sebelum menerapkan model pembelajaran, guru harus mengkondisikan siswa, agar siap berlatih berbicara bersama teman-teman di dalam kelompoknya masingmasing dengan beragam aktivitas yang harus dilakukan dan memberikan penjelasan materi yang akan dipelajar, dan (3) melaksanakan evaluasi secara komprehensif.

\section{DAFTAR RUJUKAN}

Adnyana, K. J., Lasmawan, I. W., dan Koyan, I. W. 2013. Pengaruh Model Pembelajaran Rekonstruksi Sosial terhadap Keterampilan Berfikir Kreatif dan Pemahaman Konsep IPS. e-Journal Program Pascasarjana Universitas Pendidikan Ganesha, 3, 1-12.

Banks, J. 1993, Multicultural Eeducation: Historical Development, Dimension, and Practice. Review of Research in Education.

------, J. A. 2007. Educating citizens in a multicultural society. New York: Teachers College Columbia University.

Bloom, Benyamin S. 2010.Kerangka Landasan Untuk Pembelajara, Pengajaran Dan Asesmen (Edisi Revisi). Yogyakarta: Pustaka Pelajar.

Dantes, N. 2014. Landasan Pendidikan: Tinjauan dari Dimensi Makropedagogis. Yogyakarta: Graha IImu.

Farisi, M. I. 2015. Typology of Scientific Contestation and Consensus in Indonesian Community of the Social Studies for Building a Shared Paradigm. American Journal of Social Science Research, 1(2), 57-62.

Farris, P. J. dan Cooper, S. M. 1994. Elementary Social Studies: A Whole language Approach. lowa: Brown\&Benchmark Publishers.

Haris, lyus Akhmad. dan Lasmawan, I Wayan. 2018. "Pengembangan Model Pendidikan Karakter Berbasis Tekno humanistik dan Paradigma Rekontruksi Sosial Vygotsky bagi Siswa Sekolah Dasar". UNDIKSHA.

Lasmawan, I. W. 2010. Menelisik Pendidikan IPS dalam Perspektif Kontekstual Empiris. Singaraja: Mediakom Indonesia Press Bali. -, I. W. 2019. Kurikulum, Kearipan Lokal dan Era Disrupsi. Surabaya: CV. Obor Mas Bangsa. 
2019. Spectrum of Social Studies: Testing of the Social Reconstruction Vygotsky's Paradigm in Elementary Schools Social Studies Learning. Jurnal Pendidikan Indonesia (JPI). Vol. 8 No. 1, April 2019.

Nalova, E. M. 2017. Education and Peace Building: The Role of the Teacher within and Beyond the School. The International Journal Of Humanities \& Social Studies, 5(3), 184-187.

National Commission of The Social Studies (NCSS). 2017. The New Paradigma of Social Studies Education in Global Society. Washingthon DC, Singapore: McMilland Publisher,inc.

Pranata, R., Lasmawan, I. W., dan Marhaeni, A. A. I. N. 2013. Pengaruh Implementasi Model Rekonstruksi Sosial Vigotsky dengan Teknik Scaffolding terhadap Sikap Sosial dan Prestasi Belajar IPS. e-Journal Program Pascasarjana Universitas Pendidikan Ganesha, 3, 1-12.

Tiara, S. K. dan Sari, E. Y. 2019. Analisis Teknik Penilaian Sikap Sosial Siswa Dalam Penerapan Kurikulum 2013 di SDN 1 Watulimo. EduHumaniora: Jurnal Pendidikan Dasar, 11(1), 21-30. 